\title{
ДЖЕРЕЛОЗНАВСТВО
}

УДК 94 (477)

\section{ЗУНР: ІСТОРИЧНА ПАМ'ЯТЬ КРІЗЬ ПРИЗМУ СПОГАДІВ ПРЕДСТАВНИКІВ ДІАСПОРИ}

\author{
Ірина СКАКАЛЬСЬКА \\ Кременеиька обласна гуманітарно-педагогічна академія імені Тараса Шевченка, \\ кафедра української філологіі, \\ пров. Лічейний, 1, 47003, Кременець, Тернопільська область, Україна \\ e-mail:IrunaS@ukr.net \\ DOI: 10.15330/gal.32.205-209 \\ ORCID: 0000-0001-8705-7971
}

\begin{abstract}
Мета дослідження: проаналізувати ключові сюжетні лінї у спогадах учасника підготовки Листопадового зриву, матеріалів з перебігу украӥнсько-польської війни, видання бувиих вояків украӥнців та ін. Основні завдання: узагальнити інформацію з історії ЗУНР, акумульовану у спогадах; здійснити порівняння джерел, виокремити цікаві дані, щуо дозволить більш колоритно відтворити революційні подї; висвітлити рефлексію учасників визвольних змагань. Під час дослідження послуговувались методом "текстової епохи".

Методологія дослідження спирається на регіоналістичні підходи вивчення проблеми. У ході дослідження використовувались загальнонаукові методи. Насамперед, метод збирання фактичних даних (нагромадження фактів) і метод їх компонування (аналізу). Також було застосовано спеціальні методи (біографічний, джерелознавчого аналізу), які допомагають схарактеризувати інформацію учасників революиійних подій.

Наукова новизна полягає в окресленні маловідомих спогадів з історії ЗУНР, які не були ключовими особами державотворення, але їхня інформація є важливою для збереження історичної пам'яті.

Висновки. Спогади учасників революиії, які були зафіксовані в діаспорі, а тому збереглися, деталізують події періоду ЗУНР та допомагають зрозуміти обставини, процеси, чинники, які визначали хід національно-визвольних змагань 1917-1921 рр. Спогади таких малознаних учасників заслуговують на увагу як джерело вивчення державницьких змагань українського народу. Лише комплексний аналіз всіх наявних джерел дозволить всеохоплююче висвітлити історію ЗУНР.
\end{abstract}

Ключові слова: спогади, учасники револючійно-воєнних подій, ЗУНР, історична пам'ять, diacnopa.

Постановка проблеми. В історії українського державотворення важливе місце посідає період національно-демократичної революції 1917-1921 pp. Восени 1918 р. Перша світова війна підходила до завершення. Визвольні змагання, що розпочались на території двох імперій - Російської та Австро-Угорської саме в момент їхнього розпаду, охопили значну кількість люду

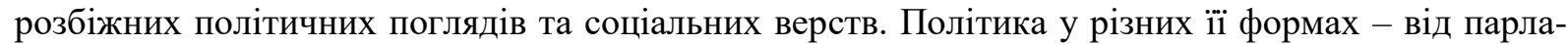
ментської до збройної - втягнула в себе людей, котрі змушені були відійти від буденного життя. Період боротьби за Українську державність, що припадає на 1917-1921 рр. визначальний тим, що значна частина сучасників залишила свої мемуари про ці роки. Серед мемуаристів зустрічаємо представників різних прошарків населення - від політиків, котрі очолювали українську державу в певний історичний період та воїнів до звичайних учасників революції. Власне, спогади простих людей, які крізь призму своїх бачень висвітлюють події, дозволяють досліднику відчути тогочасні реалії.

Велика кількість політичних діячів різних рангів, що після поразки ЗУНР опинилася в еміграції, створила певний масив науково-мемуарної літератури, яка містить як наукові дослідження, так і просто спогади 3 ліричними відступами, переживаннями автора, але завдяки цьому колоритно передає особливості того часу і боротьби українців за незалежність. Такі джерела, як спогади, дозволяють досліднику краще пізнати час та обставини визвольної епохи. У даному контексті наведемо твердження Л. Цегельського про те, що “Спогади - це не історія, 
це тільки матеріал для історика"1. Відповідно, метою нашої наукової розвідки $є$ аналіз ключових сюжетних ліній у спогадах учасників підготовки та здійснення Листопадового зриву, матеріалів 3 перебігу українсько-польської війни тощо, видання бувших вояків українців діаспори для формування історичної пам'яті.

Аналіз останніх досліджень і публікацій. Аналіз спогадів відомих державних діячів ЗУНР вже неодноразово були предметом наукових досліджень. Так, у публікації В. А. Пархоменко розглянуто становлення ЗУНР крізь призму мемуарної літератури ${ }^{2}$. Проте маловідомими $\epsilon$ спогади учасників революційних подій, які не були ключовими особами державотворення, але їхня інформація є важливою для збереження історичної пам'яті.

Виклад основного матеріалу. Спогади видані під криптонімом О. Т. у Лондоні “Об'єднанням бувших вояків українців” наводять цікаві дані про українську національно-демократичну революцію 1917-1921 pp., але історії ЗУНР приділена незначна увага. Так, згадується Акт Злуки ${ }^{3}$ і ще небагато інформації про Галицьку Армію. Тобто маємо лише фрагментарну інформацію. Проте Листопадовому зриву є більше присвячених спогадів. Для порівняння наведемо опис фактів Листопадового чину в офіційній історіографії, так В. Пархоменко окреслює хід подій, які вже $\epsilon$ відомі серед істориків ${ }^{4}$. Також у виданнях, які присвяченні історії ЗУНР зустрічаємо приблизно таку інформацію, що як і передбачалося планом, 1 листопада 1918 р. о четвертій годині ранку у Львові розпочалося збройне повстання. На ранок українцями були зайняті всі урядові будинки та стратегічні пункти міста: намісництво, міська ратуша, Галицький краєвий банк, головний вокзал, пошта, телеграф, військові склади. У відповідності з оперативним планом було нейтралізовано австро-угорські військові частини, а також обеззброєно польських солдатів та офіцерів львівського гарнізону, інтерновано намісника Гуйна, командуючого військами Галичини і Буковини маршала Пфеффера 5 .

У той же час, у своїх спогадах, військовий М. Зашко детально описує зазначені події Листопадового зриву і при цьому дає їм оцінку з точки зору власного світогляду, наводить деталі, які не $\epsilon$ відомі широкому загалу українців. Окреслюючи хід зібрання перед виступом він вказує на такий момент, що "Нарада мала дуже поважний, піднесений, але й нервовий характер. Це ж сини Галицької і Буковинської землі, виховані в конституційній державі, призвичаєні переважно до легальної праці й до послуху владі... мали йти на великий, небувалий подвиг"б. Учасник передає тогочасний настрій та хвилювання серед людей. Зокрема, інший автор I. Стебельський, який теж описує події Листопадового зриву, повідомляє, що інформацію про повстання та про те, що 1 листопада 1918 р. необхідно роззброїти все австрійське військо у повіті, українська інтелігенція, яка зібралась в Калуші, сприйняла неоднозначно. Так, “При замкнених дверях, в домівці Хлопського Союзу, відчитав я одержаний наказ, який у всіх нас приявних викликав нечувану радість і небувалу бадьорість та готовність сповнити його... На лицях видно було готовність посвяти для будови своєї власної держави. Один лише одинокий суддя Білинський, $з$ переляку блідий як труп, не виявляв жодного зацікавлення. Запитаний, чого так трясеться, відповів, що це є бунт проти цісаря і Австрії, і на таке діло він не піде ніколи"”. Цей

\footnotetext{
${ }^{1}$ Цегельський Л. Від легенд до правди. Нью-Йорк, 1960. С. 9.

${ }^{2}$ Пархоменко В. А. Становлення ЗУНР (листопад 1918 р.) в українській мемуаристиці. URL: http://irbisnbuv.gov.ua/cgi-bin/irbis_nbuv/cgiirbis_64.exe?C21COM=2\&I21DBN=UJRN\&P21DBN=UJRN\&IMAGE_ FILE_DOWNLOAD=1\&Image_file_name=PDF/Ltkp_2013_72_16.pdf.

${ }^{3}$ О. Т. Визвольна боротьба українського народу 1917-1921 р. Лондон, 1950. С. 37.

${ }^{4}$ Пархоменко В. А. “Листопадове повстання 1918 р. у Галичині в мемуарній літературі”. Украӥнський історичний журнал. 2013. № 2. C. 95. URL: http://dspace.nbuv.gov.ua/bitstream/handle/123456789/106473/06Parkhomenko.pdf?sequence $=1$.

${ }^{5}$ Полянський O. Західно-Українська Народна Республіка. URL: http://repository.ldufk.edu.ua/bitstream/ $34606048 / 5798 / 1 / \% \mathrm{D} 0 \% 9 \mathrm{~F} \% \mathrm{D} 0 \% \mathrm{BE} \% \mathrm{D} 0 \% \mathrm{BB} \% \mathrm{D} 1 \% 8 \mathrm{~F} \% \mathrm{D} 0 \% \mathrm{BD} \% \mathrm{D} 1 \% 81 \% \mathrm{D} 1 \% 8 \mathrm{C} \% \mathrm{D} 0 \% \mathrm{BA} \% \mathrm{D} 0 \% \mathrm{~B} 8 \%$ D0\%B9\%20\%D0\%9E..pdf: 9.

${ }^{6}$ Зашко М. Перший листопада у Львові. Спомин. Альманах “Гомону України”. 1980. № 51. С. 71.

${ }^{7}$ Стебельський І. Листопадовий переворот 1918 року у Калуші. Альманах “Гомону Украӥни”. 1978. № 49. C. 44 .
} 
епізод ілюструє, що частина українців з початком революційних подій не усвідомила, що власне відбувається і як бути в такій ситуації.

Також М. Зашко повідомляє про план повстання, який поставило перед вояками командування, що “наш 15-тий полк, що був чисельно найсильніший, мав зайняти такі об'єкти: головний двірець, дім державної жандармерії, головну пошту, австро-угорський банк, обі власні касарні на вул. Яблоновських і Курковій, намісництво і Військову команду"8. Розуміємо, що це не повний перелік установ для захоплення, уточнює цей список та вказує виконавців плану дослідник М. Литвин у праці “Українсько-польська війна 1918-1919”, посилаючись на спогади І. Рудницького 9 .

Зрозуміло, що автори спогадів неодноразово зупиняються і на особистих переживаннях та емоціях напередодні Листопадового зриву, зокрема, М. Зашко пише: “Якийсь час говорили ми на тему нашого збройного виступу, а опісля лягли, щоб трохи відпочити. В годині пів до третьої мав нас, на випадок, якщо ми заснули б, збудити господар, українець, який зобов'язався цілу ніч не спати. Та сон не брався... хотілося встати і йти чимскоріше до діла" ${ }^{10}$. Саме такі епізоди із спогадів дозволяють вловити настрої народу, вояків напередодні революційних подій. У той же час документи такого повідомити не можуть, а історія краще сприймається, особливо учнями чи студентами через емоції, коли вона “оживлена", а не просто безлика.

Символом нового порядку у Львові став синьо-жовтий прапор над міською ратушею. Так, як свідчить М. Зашко, що “Біля 10 години прийшов до нас післанець з Начальної Команди 3 Народного Дому. Він приніс відомість, що на ратуші і намісництві повівають блакитно-жовті прапори, передав нам відозву УНР, а ії початок звучав: "Український Народе! Голосимо Тобі вість про Твоє визволення з віковічної неволі. Віднині Ти господар своєї землі і вільний горожанин Української держави"11.

Спогади М. Шкільника, який народився на західноукраїнських землях, в часи революції 1917-1921 років працював у міністерстві торгівлі та промисловості і закордонних справ, присвячені більше гетьманату Скоропадського. У своїх мемуарах М. Шкільник дає оцінку визвольних змагань. Як зазначає автор, що гетьман Скоропадський відмовився надавати будь-яку допомогу УГА. Лише самостійник I. Луценко без відома гетьмана на Херсонщині організував військовий загін ім. Гонти під проводом отамана Долуди. Цей загін дістався до УГА та відзначився у війні з поляками ${ }^{12}$. Саме такі невеликі свідчення доповнюють загальну ситуацію у якій опинилась ЗУНР та їі армія, фактично без підтримки.

Сотник австрійської армії, а згодом УГА, Олекса Кузьма у своїх спогадах “Листопадові дні. 1918 р."13, які появилися друком 1931 р. (разом з ілюстраціями та шкіцами) окреслює передумови, причини та самі революційні події. Його відомості містять власні думки та аналіз фактів. Також О. Кузьма зафіксував важливі революційні моменти, крізь призму світогляду військового, а також опираючись на тогочасні джерела, здебільшого публікації у журналах та газетах (список ним додається наприкінці книги). Так, автор вказуючи деталі подій у Львові, після Листопадового зриву, передає піднесений настрій українців, зокрема, “Своє, українське військо являється їм людьми неначе 3 казки. I дехто старший не може стриматись, щоб у присутності сердешної радості не заступити воякові дорогу, щоб стиснути міцно його руку, подякувати та побажати щастя" ${ }^{4}$. Також у спогадах О. Кузьма подає власні узагальнення та грунтовні висновки про причини невдачі українського державотворення. Його концептуальне бачення історичних подій листопада 1918 р. важливе для розуміння початкового етапу формування західноукраїнської держави.

\footnotetext{
8 Зашко М. Перший листопада... С. 71.

9 Литвин М. Українсько-польська війна 1918-1919. Львів, 1998. С. 39.

${ }^{10}$ Там само. С. 72.

${ }^{11}$ Там само. С. 74.

12 Шкільник М. Україна у боротьбі за державність в 1917-1921 роках. Спомини і роздуми. Торонто, 1971. C. 344.

${ }^{13}$ Кузьма О. Листопадові дні. 1918 рік. Нью-Йорк, 1960. 450 с.

${ }^{14}$ Там само. С. 71.
} 
Цікавими для розуміння значення Української національно-демократичної революції, передача інформації про події, зрештою збереження історичної пам'яті серед різних поколінь, $\epsilon$ спогади, які розміщено в альманасі “Гомін України” А. Гладиловича “Очима дитини. Спогад про листопад 1918 р. і війну з поляками”. Як зауважує сам мемуарист, що, “покоління, до якого належить автор спогаду, виростало на свіжій традиції відновленої в 1917 і 1918 роках Української держави". Автор змальовує історичне середовище зазначеної доби. На підтвердження розуміння А. Гладиловичем тогочасної ситуації наведемо такі уривки з його твору: “я завидував учасникам визвольних змагань, що вони мали щастя боротися з рушницею в руках за волю України або брати участь у будівництві їі державного життя" або “наші співали тоді "Ще не вмерла Україна" із радості, що в'їжджаємо на територію вільної України" "15. Саме такі епізоди $\epsilon$ частиною історичної пам'яті народу та сприяють вихованню патріотизму українців.

Отже, спогади учасників революції, які були зафіксовані в діаспорі, а тому збереглися, деталізують події періоду ЗУНР та допомагають зрозуміти обставини, процеси, чинники, які визначали хід національно-визвольних змагань 1917-1921 рр. Наше минуле, то є постійна боротьба за власну ідентичність, державність - все це відображають спогади, щось детально, а дещо фрагментарно. У мемуарах відчутне становище суспільства, зокрема, стан постійної війни, що супроводжував ЗУНР з перших годин іiі існування, і котрий врешті-решт спричинив іiі падіння.

Мемуарна література донесла нам не лише перебіг окремих історичних випадків, а й їх бачення очима сучасників, які говорять до нас “мовою подробиць". Тематика офіційних публікацій або знаних мемуаристів групується навколо Листопадового зриву, проблем створення УГА та українсько-польської війни, організаційної діяльності ЗУНР, проте панорамне відтворення подій національно-визвольних змагань пропонують спогади-замітки маловідомих авторів, про окремі епізоди, які яскраво доповнюють відомості про тогочасні події. На нашу думку, спогади таких малознаних учасників теж заслуговують на увагу, як джерело вивчення державницьких змагань українського народу. Лише комплексний аналіз всіх наявних джерел дозволить всеохоплююче висвітлити історію ЗУНР.

\title{
ZUNR: HISTORICAL MEMOIRS OF THE DIASPORA'S REPRESENTATIVES
}

\author{
Iryna SKAKALSKA \\ Kremenets Regional Humanities and Pedagogical Academy named after Taras Shevchenko, \\ Department of Ukrainian Philology, \\ prov. Lyceum, 1, 47003, Kremenets, Ternopil region, Ukraine \\ e-mail:IrunaS@ukr.net
}

The purpose of the research: to analyze the key storylines in the memoirs of the participant in the preparation of the November disruption, materials on the progress of the Ukrainian-Polish war, the publication of the former soldiers of Ukrainians, etc. The main tasks are: to summarize the information on the history of ZUNR, accumulated in memoirs; to make a comparison of the sources, to select interesting data that will allow more colorful reproduction of revolutionary events; highlight the reflection of the participants in the liberation struggle. During the study, they used the method of "text era".

The research methodology is based on regionalist approaches to studying the problem. In the course of the study, general scientific methods were used. First of all, the method of collecting factual data (accumulation of facts) and the method of their layout (analysis). Also, special methods (biographical, source-analysis analysis) were used to help characterize the information of participants in revolutionary events.

The scientific novelty consists in the outline of little-known memoirs on the history of the ZUNR.

Conclusions Memoirs of the participants of the revolution, which were recorded in the diaspora, and therefore preserved, detail the events of the ZUNR period and help to understand the circumstances, processes, factors that determined the course of national liberation competitions 1917-1921. Memoirs of such ignorant

\footnotetext{
${ }^{15}$ Гладилович А. Очима дитини. Спогад про листопад 1918 р. і війну з поляками. Альманах “Гомону України”. 1978. № 49. С. 51-59.
} 
participants deserve attention as a source of study of the state competitions of the Ukrainian people. Only a comprehensive analysis of all available sources will allow us to comprehensively cover the history of the ZUNR. diaspora.

Keywords: memories, participants of revolutionary-military events, ZUNR, historical memory,

\section{REFERENCES}

Hladylovych A. Ochyma dytyny. Spohad pro lystopad 1918 r. i viinu z poliakamy. Almanakh "Homonu Ukrainy”. 1978. № 49. S. 51-59. [in Ukrainian].

Kuzma O. Lystopadovi dni. 1918 rik. Niu-York, 1960. 450 s. [in Ukrainian].

Lytvyn M. Ukrainsko-polska viina 1918-1919. Lviv, 1998. S. 39. [in Ukrainian].

O. T. Vyzvolna borotba ukrainskoho narodu 1917-1921 r. London, 1950. S. 37. [in Ukrainian].

Parkhomenko V. A. "Lystopadove povstannia 1918 r. u Halychyni v memuarnii literaturi”. Ukrainskyi istorychnyi zhurnal. 2013. № 2. S. 95. URL: ttp://dspace.nbuv.gov.ua/bitstream/handle/123456789/106473/06Parkhomenko.pdf?sequence=1. [in Ukrainian].

Parkhomenko V. A. Stanovlennia ZUNR (lystopad 1918 r.) v ukrainskii memuarystytsi. URL: http://irbis-nbuv.gov.ua/cgi-bin/irbis_nbuv/cgiirbis_64.exe?C21COM=2\&I21DBN=UJRN\&P21DBN= UJRN\&IMAGE_FILE_DOWNLOAD=1\&Image_file_name=PDF/Ltkp_2013_72_16.pdf. [in Ukrainian].

Polianskyi O. Zakhidno-Ukrainska Narodna Respublika. URL: http://repository.ldufk.edu.ua/bitstream/ $34606048 / 5798 / 1 / \%$ D0\%9F\%D0\%BE\%D0\%BB\%D1\%8F\%D0\%BD\%D1\%81\%D1\%8C\%D0\%BA\%D0\%B8\% D0\%B9\%20\%D0\%9E..pdf: 9. [in Ukrainian].

Shkilnyk M. Ukraina u borotbi za derzhavnist v 1917-1921 rokakh. Spomyny i rozdumy. Toronto, 1971. 344 s. [in Ukrainian].

Stebelskyi I. Lystopadovyi perevorot 1918 roku u Kalushi. Almanakh “Homonu Ukrainy”. 1978. № 49. S. 44. [in Ukrainian].

Tsehelskyi L. Vid lehend do pravdy. Niu-York, 1960. S. 9. [in Ukrainian].

Zashko M. Pershyi lystopada u Lvovi. Spomyn. Almanakh “Homonu Ukrainy”. 1980. № 51. S. 71. [in Ukrainian]. 